\title{
Arya Samaj and Caste System: A Study of in United Provinces
}

\author{
Meera \\ Research Scholar, Department of History Babasaheb Bhimrao Ambdkar Central University Lucknow (U.P) \\ India.
}

\begin{abstract}
This paper traces the views of Swami Dayanand Saraswati on Varnas and Caste system. This article examines the impact of the Arya Samaj in the United Provinces. It also explores the visions of Swami Dayanand Sarswati on Arya invasion. The concept of Shuddhi was a new idea of Swami Dayanand Saraswati. The idea of Dayanand grew and became powerful in the Punjab first and in entire northern India later. It shows the suddhi rite of purification for conversion, and social activities of Arya Samaj in United Provinces. This paper shows the activities of Arya Pritinidhi Sabha in United Provinces for removing untouchability.
\end{abstract}

Keywords : Aryas, Caste system, Dasyus, Shudras, Suddhi movement.

\section{Introduction}

The Arya religion, or Arya Samajism, is the result of one of the most important religious and social movements in India of the nineteenth century, and its influence has continued to grow very rapidly in the past decade. Dayanand Saraswati one of the greatest leaders ever to emerge from India, founded the Arya Samaj in 1875. From religious, cultural and political point of view, Dayanand Saraswati gave an indigenous orientation to Indian nationalism. The Arya Samaj movement was begun to revive the study of the Vedas and to worship one God. Dayanand defined Aryas as 'those who are true in word, deed and thought, promote public good and are learned'. Dayananad was violent in criticising caste system. He tried to break all barriers of caste, creed, colour which separated man from man by propagating the doctrine of the universal brotherhood based on the assumption that God is the Creator of all. He rejected the caste system as such. He held that a man born in a Brahman, kshattriya or Vaishya family should become a Shudra if his actions and temperaments are not high. But Dayanand accepted the fourfold functional division of society wherein the thinkers, the seers and the teachers occupied the highest place; but opposed the rigidity of any such system and especially the creed of untouchability.

\section{Brief account of the doctrine of the Arya Samaj :}

Swami Dayanand Saraswati, the founder of the Arya Samaj, commenced preaching this new doctrine he admitted that he was not founding a new religion and that his sole aim was to purge the prevailing Hinduism of the evils that had crept into the pure form of Vedicism, and to rehabilitate the Vedic theology. He maintained that he wanted the Aryas (the name he gave to the Hindu community in general) to follow the correct interpretations of the Vedas, and the philosophy professed by Gautam, kapil, Vyas Harish Chandra and Krishna. To him the true religion was the 'Vedas', and he believed that the Veda are the revelation of God which he sends at the time of every cosmos, through the four Rishis, Agni, Vayu, Aditya and Angirah. The Arya Samaj follows this doctrine and, in fact, it forms the sheet-anchor of the Samaj. ${ }^{1}$ Literature of the Arya Samaj are the Shastras, the Upanishads, the Brahman Granthas, the Vedangas, and the Smritis, the last of these being acceptable only in so far as they are in consonance with the Vedas. The Aryas reject everything that is not in conformity with the Vedas. While founding the first Arya Samaj at Bombay in 1875, Swami Dayanand laid down the following ten principles, which all the members of the Samaj are required to subscribe to and act upon

1) God is the primary cause of all true knowledge, and of everything known by its means.

2) God is all truth, all knowledge, all beatitude, incorporeal, almighty, just, merciful, infinite, unchangeable, without a beginning, incomparable, the Support and the Lord of all, all-pervading, omniscient, imperishable, immortal, exempt from fear, eternal, holy and the cause of the universe. To him alone worship is due.

3) The Vedas are the books of true knowledge, and it is the paramount duty of every Arya to read and hear them, to teach and preach them to others.

4) One should always be ready to accept truth and renounce untruth.

5) All actions should be done conformably to virtue, i.e. after a through consideration of right and wrong.

${ }^{1}$ A.C. Turnes. Census of India, 1931, United Provinces of Agra and Oudh, Vol XVIII, Part-1 Report, (Allahabad: The Superintendent Printing and Stationary, United Provinces 1933). 
6) The primary object of the Samaj is to do good to the world by improving the physical, spiritual and social condition of mankind.

7) All should be treated with love, justice and due regard to their merits.

8) Ignorance should be dispelled and knowledge diffused.

9) None should be content with his own good alone; but everyone should regard his prosperity as included in that of others.

In matters which affect the general social well-being of the Samaj one should discard all differences and not allow his individuality to interfere; but in strictly personal matters every one may act with freedom.

\section{Differences between the Samaj and orthodox Hinduism -}

There are two great differences between the doctrines of the Arya Samaj and orthodox Hinduism. Firstly, the Aryas do not believe in the incarnation of God, while orthodox Hindus do. And for this reason there have arisen great differences among these two sections of the vast Hindu community, particularly regarding the Tirthas (holy places), which orthodox Hindus consider as being the specially favoured spots of God on the earth, whereas the Aryas oppose this view. Secondly, the interpretation of the Vedic Hymns as accepted by the Arya Samaj is in many respects different from that of orthodox Hindus. The Arya Samaj lent its powerful support to the passing of the Child Marriage Restraint Act (commonly called the Sarda Act) in the teeth of bitter opposition from an influential section of orthodox Hindus. Aryas oppose marriages at unequal ages as being contrary to the Shastras, while among Hindus of the orthodox school such marriages are still going on. Aryas do not believe in astrology, whereas orthodox Hindus do. ${ }^{2}$

\section{Swami Dayanand views on Arya invasion}

Swami Dayanand gives the views that the Aryas came from the Tibet and before the Aryas this country had no name, nor was it aboriginal inhabited by any other people before the Aryas (settled in it) who sometime after creation came straight down here from Tibet and colonized this country. According to Swami Dayanand at the time of creation all men belonged to one class, viz., that of man, but later on they were divided into two main classes, - the good and the wicked. The good were called Aryas and the wicked Dasyus. Says the Rig Veda, "there are two classes of men - Aryas and Dasyus." The good and learned were also called Devaas, while the ignorant and wicked, such as dacoits (robbers), were called Asura. The Aryas were again divided into four Classes, viz., Braahmana (teachers), Kshatriya (rulers or protectors), Vaishya (merchants) and Shuudra (labourers). Those who belonged to the first three classes being educated and bearing good character, were called Dwijas - twice born; whilst the fourth Class was so named because of being composed of ignorant and illiterate persons. They were also called Anaryas - not good. This division into Aryas and Shudras is supported by the Atharva Veda wherein it is said "Some are Aryas, others Shuudras. ${ }^{3}$

Dayanand rejected this caste system on the basis of colour. He cited a mantra from the YajurVeda which runs as follows: the Brahmins were born from the mouth of the Brahma, the kashattriyas from the arms, the Vaishyas from the thighs and the Shudras from the feet. Dayanand says that it is wrong and absurd. God has no mouth, no arms, no thighs, and no feet. ${ }^{4}$ The true meaning of this mantra is that this universe created and sustained by the Omnipresent God, he who is the (mukh) head, leader among men, is called a Braahman, he in whom power and strength (Baahu) reside pre-eminently in a Kshatriya. He who travels about from place to place for the purposes of trade, etc., and obtains all things (for the community) on the strength of his thighs (i.e. is the support of the community just as the thighs are that of the human body) is called a Vaishya, lastly a Shudra is like feet, the lowermost part of the body, because he is ignorant. ${ }^{5}$

He gives correct interpretation thus: The Brahmins occupy the same position in the society as the mouth in the body, kshattriyas that of arms and so on. And he proved that the whole society was nothing but a body with four distinct divisions- face, arms, thighs and feet. Just as these organs functions differently for the well-being of the whole body as well as for themselves. Similarly the human society needs four kinds of persons respectively representing wisdom strength wealth and work. Those who perform the first duty are Brahmins; those who protect are kshattriyas; those who increase wealth are the Vaishyas and those who are working and producing are the Shudras. He did not say that Varnas are useless, every society required some classification

\footnotetext{
2 Ibid.

${ }^{3}$ Maharishi Swami Dayanand Saraswati, Satyarth Prakash, Sarvadeshik Arya Pritinidhi Sabha, Maharishi Dayanand Saraswati Bhawan, New Delhi, 1975.

${ }^{4}$ Dhanpati Pandey, Builders of Modern India Swami Dayanand Saraswati , ( Publication Divisions Ministry of information and

Broadcasting Government of India, 1985) . P-86.

${ }^{5}$ Maharishi Swami Dayanand Saraswati, Satyarth Prakash, Sarvadeshik Arya Pritinidhi Sabha, Maharishi Dayanand Saraswati Bhawan, New Delhi, 1975.
} 
and the Varna classification is the best. But this should not be based on birth. The son of a Brahman can be a kshattriya, a Vaishya or even Shudra. And a Shudra's son may be a Brahman. ${ }^{6}$

'Back to the Vedas' was the first radical and militant view in which Swami Dayananda saw the protection of the Hindu community as well as the country. Connected with the radical view of Back to the Vedas was the attempt for removal of monopoly of the Brahmins. Dayanand felt that the citadel created by the Brahmins was the root of all evils of Hinduism. He questioned the authority of the Brahmins merely from right of birth. The Brahmins relied on Manu for their rights and privileges, and the swami proved, on the authority of Manu himself, that a Brahmin must be versed in the Vedas and a Brahmin who did not reach that standard did not deserve to be treated and respected as such. ${ }^{7}$

Dayanand holds that it is written in the Apastambha Sootraas that "A low Class man may, by leading a virtuous life, rise to the level of a higher Class man and he should be ranked as such. In like manner a high Class man can by leading a sinful life, sink down to the level of a Class low than his, and should be considered as such." Apastambha Sootraas, The same law applies to women in determining their Class. Dayanand holds that if a man born in a Sudra family possesses merits, actions and temperaments of a Brahmin, a kshattriya or a Vaishya, he becomes a Brahmin, a kshattriya or a Vaishya, as the case may be. Similarly a man born in a Brahmin, kshattriya or Vaishya family should become a Shudra if his merits, actions and temperaments are Shudra like. ${ }^{8}$

In the past many have become Braahmans many in the present do and many in future will. Here are some of the historical proofs. In the Chhaandogya Upnishad we read that the sage Javaal of an unknown Class became a Braahman. In the Mahabharata, it is written that Vishwaamitra, Kshatriya (second class) became a Braahman, so did the sage Maatang an Outcast by birth. Even at the present day, he who possesses the qualification, character and knowledge of a Braahman is respected as such and the ignorant are treated as Shoodraas (lowest class). So will it be in the future. ${ }^{9}$

\section{5- Social and other activities}

Swami Dayanand Saraswati raised the status of untouchables on the principle of equality. He used to say that any Shudra who was sound in mind and body had the right to be considered as Dwija (Brahmin). This approach to the problem of untuchability was yet another step in the direction of secularisation. Dayanand thought that the uplift of depressed masses of India was an important as steps to rise for liberalising the rigidities of caste system, if India was to be built up on a sound basis. Dayanand and his samaj did not consider the problem of untouchability from the religious point of view. untouchability was largely due to bad environment, association and training, and the resultant deterioration of character. The social ideas of the Samaj were the Fatherhood of God and the Brotherhood of man; the equality of sexes; absolute justice and fair-play among men and men and nations and nations, equal opportunities to all according to their nature, action, merit, and love, and charity towards all. In pursuance of these ideals the Swami along with his Samaj took great interest in the social uplift of the lower classes. Two ways were adopted (a) the raising of status of castes not entitled to wear the sacred thread by giving them that privilege, and (b) raising untouchables to the rank of touchables, and educating them to higher social ideals, with a view to eventually putting them on a footing of social equality with other Hindus. For the fulfilment of this purpose the Dayaand Dalitodhar Mandal was organised at Hoshiarpur. ${ }^{10}$

The movement has since been taken up by some orthodox Hindus, who are now beginning to open the doors of their temples of worship to them, though in their case it has to be admitted that the change in attitude is prompted chiefly by the political aspect. The Samaj has opened 43 schools in this province for the education of the children of untouchables wherein 1,296 boys and 147 girls are receiving education. ${ }^{11}$

The Arya Samaj started the Shuddhi movement to prevent low caste Hindus from embracing Christianity or Islam and to uplift them as integral part of Hinduism. The idea of the Shuddhi movement was given by Dayanand Saraswati himself. Shuddhi is a Sanskrit word which means purification. In religious terminology it is now applied to (a) conversion to Hinduism of persons belonging to foreign religions, (b)

\footnotetext{
${ }^{6}$ Dhanpati Pandey, Builders of Modern India Swami Dayanand Saraswati, ( Publication Divisions Ministry of information and Broadcasting Government of India , 1985) . P-86.

${ }^{7}$ Dhanpati Pandey :- The Arya Samaj and Indian Nationalism (1875-1920), ( Delhi :S.Chand \& Co. Pvt. Ltd., 1972,) p-29.

8 Dhanpati Pandey, Builders of Modern India Swami Dayanand Saraswati, ( Publication Divisions Ministry of information and Broadcasting Government of India , 1985). P-87.

9 Maharishi Swami Dayanand Saraswati, Satyarth Prakash, Sarvadeshik Arya Pritinidhi Sabha, Maharishi Dayanand Saraswati Bhawan, New Delhi, 1975.
}

10 Dhanpati Pandey, Builders of Modern India Swami Dayanand Saraswati , ( Publication Divisions Ministry of information and Broadcasting Government of India , 1985) . P-102.

${ }^{11}$ A.C. Turnes. Census of India, 1931, United Provinces of Agra and Oudh, Vol XVIII, Part-1 Report, (Allahabad: The Superintendent Printing and Stationary, United Provinces 1933). 
Reconversion of those who have recently or at a remote period adopted one of the foreign religions and (c) Reclamation, i.e. raising the status of the depressed classes. ${ }^{12}$ The concept of Shuddhi was a new idea of Swami Dayanand Saraswati. The idea of Dayanand grew and became powerful in the Punjab first and in entire northern India later. The Bharat Suddhi Sabha under the leadership of Pandit Ram Bhag Dutta reclaimed several thousand of people. In Lahore grand work was done among Hindu Sweepers and Chamars. In this respect the Suddhi Sabha was largely instrumental in removing the blot of untouchability from the Indian society. ${ }^{13}$

Another very important work which has recently been taken up by the Samaj is the reclamation of criminal tribes. This work has been carried on almost entirely by the Salvation Army which had established several Criminal Settlements. In November, 1929, the United Provinces Arya Pritinidhi Sabha started a settlement, known as the Aryanagar Settlement, in Lucknow district, for the reclamation of the karwals (an offshoot of the Bahelia tribe) of that district. Government gave the Sabha about 232 acres of land free of rent and other encumbrances, and a large sum of money for the construction of the necessary buildings. The Settlements was working well and 238 karwals are there employed at agriculture, weaving and other useful arts. ${ }^{14}$

Below are given figures which show the caste constitution at each of the last three censuses as far as figures are available and the percentage variations since 1911 in the actual members of Aryas who returned each caste. ${ }^{15}$

\begin{tabular}{|c|c|c|c|c|}
\hline \multirow[t]{2}{*}{ Caste } & \multicolumn{3}{|c|}{ Number per miles of Arya community in- } & \multirow{2}{*}{$\begin{array}{l}\text { Increase in actual } \\
\text { number returning caste } \\
1911-1931, \text { Per cent }\end{array}$} \\
\hline & 1931 & 1921 & 1911 & \\
\hline Total Aryas & $\mathbf{1 , 0 0 0}$ & $\mathbf{1 , 0 0 0}$ & $\mathbf{1 , 0 0 0}$ & +141 \\
\hline Brahman & 94 & 125 & 137 & +66 \\
\hline Rajput & 160 & 194 & 248 & +56 \\
\hline Vaishya & 95 & 108 & 166 & +39 \\
\hline Jat & 148 & 143 & 74 & +382 \\
\hline Kayastha & 35 & - & 91 & -7 \\
\hline $\begin{array}{l}\text { Depressed } \\
\text { castes }\end{array}$ & 136 & - & - & - \\
\hline Silpkars & 61 & - & - & - \\
\hline Chamars & 53 & 31 & 12 & +991 \\
\hline Others & 22 & - & - & - \\
\hline Others castes & 268 & - & -- & - \\
\hline $\begin{array}{l}\text { No castes or } \\
\text { caste } \\
\text { unspecified }\end{array}$ & 64 & - & - & - \\
\hline
\end{tabular}

\begin{tabular}{|l|l|l|l|}
\hline \multirow{2}{*}{ Caste } & \multicolumn{3}{l|}{ Number of Aryas who returned this caste. } \\
\cline { 2 - 4 } & 1931 & 1921 & 1911 \\
\hline Brahman & 29,811 & 25,668 & 17,970 \\
\hline Rajput & 50,859 & 39,927 & 32,659 \\
\hline Vaishya & 30,203 & 22,228 & 21,804 \\
\hline Jat & 47,024 & 29,378 & 9,765 \\
\hline Kayastha & 11,204 & - & 11,992 \\
\hline Silpkar & 19,299 & - & - \\
\hline Chamar & 16,929 & 6,398 & 1,551 \\
\hline
\end{tabular}

The disciples of the Arya Samaj have rapidly increased. A branch of the Arya Samaj was established at Etawah in 1884, with about 50 members, and at the census of 1891 it had 169 adherents. At the last enumeration this number had risen to 890. Regular meetings are now held every Sunday at a place called the Samaj Mandir in Etawah, set apart for the purpose; and at these meetings, and on other special occasions when assemblies are convened at other places, the life of Swami Dayanand and his teachings as set forth in the Satyarth Prakash are read and propounded, while hymns and songs are also recited by a band of singers on occasions of public

12 Dhanpati Pandey, Builders of Modern India Swami Dayanand Saraswati , ( Publication Divisions Ministry of information and Broadcasting Government of India , 1985) . P-104.

\footnotetext{
13 Ibid., 104.

${ }^{14}$ A.C. Turnes. Census of India, 1931, United Provinces of Agra and Oudh, Vol XVIII, Part-1 Report, (Allahabad: The Superintendent Printing and Stationary, United Provinces 1933).
}

${ }^{15}$ Ibid. 
festivals. The Samaj Mandir has attached to it a library known as the Vedic Pushtakalya, which was started in 1895 and there are six branches established at Jaswantnagar, Patna, Lahrapur, Jaitpur and Phaphund. ${ }^{16}$

The Aryas Samaj was first promulgated at Bigahpur in this district during the lifetime of the founder, Swami Dayanand Saraswati. It has however made little progress; in 1891 there were 123 Aryas, and at the last census the number had risen to 190. There are two lodges at Nawabganj and Unao, the latter having been started in 1896; but adherents of the Samaj are to be found scattered in villages all over the district such as Bigahpur, Dubepur, Pandari, Rawatpur and Perha. The Samaj maintains a school at Rawatpur of the Aryas 154 are Brahmans, the remainder being Rajputs, Banias and others. At the last census one was a Bahelia, the only Arya member of this caste in the whole of the United Provinces. ${ }^{17}$

\section{Conclusion}

Started, as it was as a crusade to purge the old Sanatan Vedic religion of the idolatrous impurities which had crept into it, and at the same time to break the superiority of Brahmans, Aryasim, like other missionary religious, has found it difficult to make much impression on the stubborn rock of Hinduism, and there is now a noticeable weakening in their campaign against the priestly Brahman. Although their numbers have increased proportionally in this province to a very considerable extent, the actual total of those who follow its doctrines is still infinitesimal compared with the Hindu community as a whole. Of late years not only have their own schemes, as has been seen above, been very materially advanced, but the Samaj's influence on the views and social activities of the orthodox Hindu community has been most marked, and has made for the amelioration of the lot of considerable numbers of the populace, which redounds greatly to the credit of the organizers and followers of the Samaj.

\footnotetext{
${ }^{16}$ D.L.Drake-Brockman, "Etawah, A Gazetteer, Being Volume XI of the District Gazetteers of the United Provinces of Agra and Oudh", Allahabad: Printed by F. Luker, Superintendent, Government Press, United Provinces. 1911.

${ }^{17}$ H.R.Nevill, "Unao, A Gazetteer, Being Volume XXXVIII of the District Gazetteers of the United Provinces of Agra and Oudh", Allahabad: Printed by F. Luker, Superintendent, Government Press, United Provinces. 1903.
} 